\title{
SEASONAL VARIATION IN THE ASCORBIC AND ORGANIC ACIDS CONTENT IN SHOOTS OF HIGHBUSH BLUEBERRY CULTIVARS DURING VEGETATION STAGES
}

Introduction. Ascorbic acid $(A A)$ and organic acids $(O A)$ are synthesized in all plants, and are an important part of their metabolism, as well as an integral part of the metabolism of the human body. The study of the mechanisms of action of highbush blueberry $(H B)$ extracts is preceded by the most detailed study of the composition, in particular $A A$ and $O A$, the content of which may vary in different physiological phases of development.

The aim of the study - to determine the content of ascorbic and organic acids in the HB shoots of three varieties at different stages of their physiological development.

Research Methods. The material for the study was shoots of blueberry (Vaccinium corymbosum L.) varieties Bluejay, Bluecrop and Elliott. The AA content was determined spectrophotometrically; the content of OA was determined titrimetrically.

Results and Discussion. As a result of the analysis, the level of $A A$ and $O A$ was almost at parity with each other in investigated varieties of $H B$. The value of $A A$ was recorded $42.61-83.62 \mathrm{mg} \cdot 100 \mathrm{~g}^{-1} \mathrm{DW}$ (the lowest is (42.61 \pm 1.828$)$ in IV phase) in Bluejay; 49.02-102.5 mg.100 g-1 DW in Bluecrop; 70.87-98.04 mg.100 g-1 DW in Elliott. Changes OA contents were within 2.19-5.26 \% in Bluejay; 3.12-7.83\% in Bluecrop, and 3.80-9.16\% in Elliott.

Conclusions. Varieties of highbush blueberries with different fruit ripening dates differ in the content of $A A$ and $O A$ in the shoots during the growing season. The shoots of $V$. corymbosum varieties Bluecrop. Bluejay, and Elliott are sufficiently high in $A A$ and $O A$ during physiological development, and can be used for further research.

KEY WORDS: Vaccinium corymbosum L.; Bluejay; Bluecrop; Elliott; ascorbic acid; organic acids.

INTRODUCTION. Ascorbic acid (AA) is synthesized by all plants is an integral part of metabolism, as it is a co-substrate for the biosynthesis of plant hormones (ethylene and gibberellic acid [1], a cofactor of prolyl hydroxylase, which hydroxylates posttranslationally the proline residues in glycoproteins of cell walls [2] and thus is responsible for cell division and growth. The presence of several (at least four) alternative pathways of AA biosynthesis in plants themselves [2,3], the main of which is L-galactose [4], provide a balance between its formation and usage. It is especially important that in different organs of the same plant the synthesis and accumulation of AA can occur differently: in young organs it is usually more active than in old ones [5]; and in generative organs, for example in fruits of different species - its content may vary depending on the development stage, leaf exports and external conditions [3]. There are a lot of confirmations, expressed more then two decades ago about the fact that $A A$ is an important nonenzymatic element in the detoxification of excess reactive oxygen species $[6,7]$, which can be formed in plants under environmental stress [8-10]. It is (c) N. Y. Yavorska, N. M. Vorobets, 2020. believed that ascorbate can effectively regulate the antioxidant metabolism in plants [7]. The mechanisms of regulation of the AA pool in plants are largely unknown, although the results of some researchers suggest that photosynthetic electron transport in chloroplasts is closely related to the regulation of AA pool size in leaves [11], which maintains the stability of some phenolic compounds [12], and thus participates in the regulation of the development plasticity and adaptation of plants in normal and stressful environmental conditions. Nevertheless an assumption that ascorbate status influences gene expression in plants and mammals, Smirnoff N. believes that "it most likely acts indirectly by influencing the redox state of thiols and 2-0xoglutarate-dependent dioxygenases activity" (2018) [13]. Detailed studies of the last twenty years show that the AA pool depends on the level of its use (oxidation) and/or effective regeneration [6] at different stages of physiological development and in different climatic conditions.

There is evidence that the metabolism of ascorbic acid in plants is associated with the metabolism of organic acids, eg. the oxalate and tartrate are derived from ascorbate [14]. Organic acids are 
intermediates of carbon metabolism in plants and key components in mechanisms of their tolerance to environmental stress [15].

For humans and many animals, AA is an ess sential substance because it provides the antioxidant potential of their bodies, although it is not synthesized or accumulated in them. However, changes in diet with the inclusion of ascorbate-containing fruits and vegetables have led "to a loss of selective pressure" and to maintain the functioning of metabolic pathways using ascorbate [16]. As a cofactor of oxidases, monooxygenases, and dioxygenases, ascorbate is involved in the prevention of scurvy [3] and cancer [17]. AA is indispensable in collagen biosynthesis [18] and carnitine [19]. In addition to the major role of antioxidant and cofactor in redox reactions, recent reports have shown the important role of ascorbate in activating epigenetic mechanisms that control cell differentiation, the dysregulation of which can lead to the development of certain cancers [3]. AA belongs to bioactive compounds and together with other groups (in particular polyphenols, flavonoids, minerals with antioxidant properties) is of great interest to nutritionists and food technologists due to the possibility of using them as functional ingredients of foods - nutraceuticals, which could reduce some risks and improve health [20].

In mammals, the metabolism of ascorbic acid and organic acids is also linked [21]. Organic acids in the human body activate the salivary glands, bile and pancreatic juice secretion, have a bactericidal effect [22]. Therefore, it is important to know the content of both ascorbic and organic acids in plant materials.

Highbush blueberry Vaccinium corymbosum L. (Ericaceae) is an aboriginal species of the American continent, which is now widely cultivated in the world and in Ukraine, as over the past century, created several hundreds of its varieties with delicious and healthy fruits. The biological value of the fruits of highbush blueberries is determined by the complex of BAS, however fruit ripening occurs in a certain seasonal period, their collection and storage is quite expensive, while the content of some biologically active compounds decreases significantly over time [23], and shoots are available throughout the year. This aspect is important because the content of BAS determines the value of the plant as a medicinal raw material or feed, and chemical composition of shoots is conditioned genetically (cultivar) and can change during physiological phases. All of the above has led to interest in studying the AA and OA content in shoots of highbush blueberries, which are a source of different groups of phenolic compounds, pigments, minerals $[24,25]$ and can potentially be a medicinal or/and feed plant material.
The aim of this study was to determine the content of ascorbic and organic acids in the shoots of highbush blueberries of three varieties at different stages of physiological development.

RESEARCH METHODS. The materials for the research were highbush blueberry ( $V$. corymbosum) varieties Bluejay (early ripening) Bluecrop (Bluecrop) (medium ripening) and Elliott (late ripening), which were obtained in vitro and grown on an experimental plot from the manufacturer Berry Partner LLC (Lviv region, Ukraine $\left(49^{\circ} 79^{\prime} 28.01^{\prime \prime} \mathrm{N} 24^{\circ} 0 \mathrm{TO0} .39^{\prime \prime} \mathrm{E}\right)$. Samples of shoots $15-20 \mathrm{~cm}$ long were harvested during 2018-2019 in phenological phases: flowering (I), fruiting (II), after fruiting (III), the period of preparing for winter dormancy (IV). Plant raw materials were dried in air in the dark at a temperature of $22-24^{\circ} \mathrm{C}$ to air-dry state and stored until use.

The ascorbic acid content was determined spectrophotometrically by the method described by Hewitt, Dickes, 1961 [26]. A portion of the plant material was homogenized with $2 \%$ metaphosphoric acid in a ratio of 1:10 (weight:volume/g:ml). The homogenate was transferred to a $50 \mathrm{ml}$ volumetric flask. The volume was made up with $2 \%$ $\mathrm{HPO}_{3}$ and $0.21 \mathrm{M} \mathrm{Na}_{3} \mathrm{PO}_{4}$, taken in a ratio of 3:2 $(\mathrm{V}: \mathrm{V}, \mathrm{pH} 7.3$ repeted 7.4). The extract was centrifuged for $15 \mathrm{~min}$ at $3000 \mathrm{rpm}$, the optical density was measured on a spectrophotometer at $265 \mathrm{~nm}$ against the standard, the above solutions of $\mathrm{HPO}_{3}$ and $\mathrm{Na}_{3} \mathrm{PO}_{4}$, taken in the same ratio. The results were calculated by the formula: AA content, $\mu \mathrm{M}=$ extinction at $265 \mathrm{~nm} \times \mathrm{V} \mathrm{ml} / \mathrm{molar}$ extinction coefficient for AA at $265 \mathrm{~nm}$. The molar extinction coefficient for $\mathrm{AA}$ at $265 \mathrm{~nm}$ and $\mathrm{pH}=6.8$ and above is equal to $1.65-1.655 \times 10^{4}$. The AA content was expressed in $\mu \mathrm{g}$ per $\mathrm{g}$ of dry weight (DW). A calibration curve was used for comparison, the equation obtained for the calibration curve with ascorbic acid has taken as standard: $y=0.0927 x+0.0303$, $\mathrm{R}^{2}=0.9951$.

Quantitative determination of the content of free organic acids in air-dry plant raw materials was performed by direct alkalimetric titration with sodium hydroxide solution in the presence of indicators of methylene blue and phenolphthalein [State Pharmacopoeia of Ukraine, 2015 [27]. $10 \mathrm{ml}$ aliquot of the sample solution was pipetted into a $200 \mathrm{ml}$ conical flask and $100 \mathrm{ml}$ of freshly boiled distilled water, 6 drops of $1 \%$ alcohol solution of phenolphthalein, 12 drops of alcohol solution of methylene blue were added. The sample was titrated with sodium hydroxide solution $\left(0.01 \mathrm{~mol} \cdot \mathrm{L}^{-1}\right)$. The endpoint of the titration was identified as the first permanent trace changed from green-blue to purple. The titration was repeated with further aliquots of sample solution until concordant results were 
obtained. The end point of titration in case of plant sample varies according to the colour of the used extract. The titration was considered complete when the solution created a purple color that lasted for longer than 20 seconds. The final volume of the sodium hydroxide solution in the burette was recorded. The difference between the initial volume and the final one was calculated and used to calculate the amount of the organic acids in samples. The procedure was repeted 3 times. Malic acid was taken as standard and the organic acid content was expressed as malic acid equivalent in $\%$ and dry raw materials. The equation of a calibration curve for malic acid (within the limits $0.05-1.0 \%)$ : $y=16.26 x+0.310\left(R^{2}=l\right)$.

Statistical analysis of the results was performed using the Microsoft Office Excel software package (2007). The results are given as the mean \pm standard deviation $(M \pm S D)$. Statistical certainty (significance) of the obtained results was evaluated by t-test (Student). The results were considered statistically significant at $p<0.05$.

RESULTSAND DISCUSSION. Soil and climatic conditions of the Western regions of Ukraine correspond to the biological properties of Bluecrop, Bluejay and Elliott varieties. For the purpose of their detailed research we persued a study of ascorbic and organic acids in their shoots at different phases of physiological development, the results of which are given in Table 1. In Bluejay, the AA content was little different in phase I, II, III and was twice as low in phase IV, and was relatively little different over the years of observation.

In Bluecrop, the AA content in the shoots varied in a different way in physiological phases and over the years, although the level of content did not differ much from Bluejay. In 2018, Bluecrop shoots had the highest AA during fruiting, and in 2019, the highest AA was during flowering and half as much during fruit ripening. A relatively high level of $A A$ was in Elliott's shoots of both years. In general, the same level of AA content was observed in the studied varieties.

Total content of organic acids in the shoots of investigated highbush blueberries is presented in table 2. In the first year of our study, Bluecrop and Bluejay had the highest content of OA in phase I, in II - 1.5-2 times lower, and in phase III and IV, the content increased again; in the second year of the study, the OA content increased from I to III. In Elliott, the highest content of OA was in the flowering phase, lower in subsequent phases of development and lowest in the dormant phase.

As far as raw material samples were taken from plants grown under the same conditions, the differences in $A A$ and $O A$ content may reflect the genetic characteristics of the varieties. The level of $A A$ and $O A$ in the shoots of varieties is relatively high to be considered active in this plant material. $A A$ is a powerful antioxidant which protects the human body from several diseases, in particular induced by free radicals, and at the same time with minimum or no side effect. The level of $A A$ in the shoots of both varieties indicates that it can have a beneficial effect on human health due to the high bioavailability and synergistic interaction with other BAS in their composition as shown for other species $[28,29]$.

Although ascorbic and organic acids do not a very significant proportion of the total V. corymbosum constituents, they make important contributions to chemical properties of their extracts. OA used as additives in food may change off internal equilibrium in human body. Beneficial effects on intestinal health and general metabolism of pigs' are known in used organic acids, so natural source of them is valuable [30]. Varieties of $\mathrm{V}$. corymbosum require a more

Table 1 - The content of ascorbic acid in the shoots of highbush blueberries in different physiological phases, $\mathrm{mg} \cdot 100 \mathrm{~g}^{-1} \mathrm{DW}(\mathrm{n}=3)$

\begin{tabular}{|c|c|c|c|}
\hline \multirow{2}{*}{ Variety } & \multirow{2}{*}{ Stage of vegetation } & \multicolumn{2}{|c|}{ Year } \\
\hline & & 2018 & 2019 \\
\hline \multirow[t]{4}{*}{ Bluejay } & $\mathrm{I}$ & $71.52 \pm 2.093$ & $76.41 \pm 2.448$ \\
\hline & II & $74.67 \pm 6.771^{*}$ & $69.57 \pm 1.119^{\star \star \star}$ \\
\hline & III & $83.62 \pm 4.785^{\star \star \star}$ & 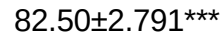 \\
\hline & IV & $55.00 \pm 3.974^{\star \star}$ & $42.61 \pm 1.828^{\star \star \star}$ \\
\hline \multirow[t]{4}{*}{ Bluecrop } & $\mathrm{I}$ & $62.07 \pm 0.263$ & $102.5 \pm 1.670$ \\
\hline & II & $82.28 \pm 3.140^{\star \star \star}$ & $49.02 \pm 2.306^{\star \star *}$ \\
\hline & III & $109.78 \pm 0.381^{\star \star \star}$ & $88.15 \pm 0.110^{\star \star *}$ \\
\hline & IV & $93.99 \pm 5.613^{\star \star}$ & $87.94 \pm 3.092^{*}$ \\
\hline \multirow[t]{4}{*}{ Elliott } & $\mathrm{I}$ & $70.87 \pm 0.209$ & $75.33 \pm 0.279$ \\
\hline & II & $72.07 \pm 0.546^{\star \star \star}$ & $97.28 \pm 0.238^{\star \star *}$ \\
\hline & III & $70.76 \pm 0.530$ ** & $84.13 \pm 0.410^{\star \star *}$ \\
\hline & IV & $85.00 \pm 0.241^{\star \star \star}$ & $98.04 \pm 0.398^{\star \star \star}$ \\
\hline
\end{tabular}

Note: 1 . Stages of vegetation: flowering - I, fruiting - II, after fruiting - III, the period of preparing for winter dormancy - IV. 2. * $-p<0.05 ;{ }^{* \star}-p<0.01 ;{ }^{* \star \star}-p<0.001$. 
Table 2 - Total content of organic acids in the shoots of highbush blueberries in different physiological phases, \% of DW in malate equivalent $(n=3)$

\begin{tabular}{|c|c|c|c|}
\hline \multirow{2}{*}{ Variety } & \multirow{2}{*}{ Stage of vegetation } & \multicolumn{2}{|c|}{$\overline{\text { Year }}$} \\
\hline & & 2018 & 2019 \\
\hline \multirow{4}{*}{ Bluejay } & $\mathrm{T}$ & $6.09 \pm 0.550$ & $2.19 \pm 0.502$ \\
\hline & II & $2.71 \pm 0.336^{\star \star \star}$ & $2.91 \pm 0.462^{\star \star}$ \\
\hline & III & $4.52 \pm 0.431^{\star \star}$ & $4.24 \pm 0.778^{\star \star}$ \\
\hline & IV & $5.26 \pm 0.584^{\star \star \star}$ & $4.76 \pm 0.251^{*}$ \\
\hline \multirow{4}{*}{ Bluecrop } & I & $5.37 \pm 0.605$ & $3.94 \pm 0.337$ \\
\hline & II & $3.63 \pm 0.550^{\star \star \star}$ & $3.12 \pm 0.463^{\star \star}$ \\
\hline & III & $4.00 \pm 0.384^{*}$ & $4.04 \pm 0.502^{\star \star}$ \\
\hline & IV & $6.99 \pm 0.179 * *$ & $7.83 \pm 0.463^{\star \star \star}$ \\
\hline \multirow{4}{*}{ Elliott } & I & $9.16 \pm 0.550$ & $7.01 \pm 0.332$ \\
\hline & II & $6.09 \pm 0.674^{\star \star \star}$ & $3.53 \pm 0.462^{\star \star \star}$ \\
\hline & III & $4.76 \pm 0.719 * \star \star$ & $5.68 \pm 0.926^{\star \star \star}$ \\
\hline & IV & $3.80 \pm 0.827^{*}$ & $4.04 \pm 0.930^{\star \star \star}$ \\
\hline
\end{tabular}

Note: 1. Stages of vegetation: flowering - I, fruiting - II, after fruiting - III, the period of preparing for winter dormancy - IV. 2. * $-p<0.05 ;{ }^{* *}-p<0.01 ;{ }^{* *}-p<0.001$.

detailed chemical characterization, given the importance of their consumption.

CONCLUSIONS. Varieties of highbush blueberries with different fruit ripening dates differ in the content of $A A$ and $O A$ in the shoots during the growing season. The results of our investigations demonstrate that the shoots of $\mathrm{V}$. corymbosum varieties Bluecrop, Bluejay, Elliott are sufficiently high in $A A$ and $O A$, and can be used for further research of the mechanisms of action their extracts as therapeutic agents for the prevention of various diseases associated with free radicals and metabolic desorders in human and animals.

Funding. This research received no external funding.

Conflict of Interests. The authors declare no conflict of interest.

Author Contributions. N. Y. Yavorska-formal analysis, investigation, writing - original draft; N. M. Vorobets - conceptualization, supervision, writing - review \& editing.

\section{LITERATURE}

1. Plant L-ascorbic acid: chemistry, function, metabolism, bioavailability and effects of processing / M. W. Davey, M. Van Montagu, D. Inzé [et al.] // J. Sci. Food Agric. - 2000. - 80. - P. 825-860.

2. Smirnoff N. Ascorbic.acid in plants: biosynthesis and function / N. Smirnoff, G. L. Wheeler // Crit. Rev. Biochem. Mol. Biol. - 2000. - 35, No. 4. - P. 291-314.

3. Fenech M. Vitamin C content in fruits: biosynthesis and regulation. / M. Fenech, I. Amaya, V. Valpuesta, M. A. Botella // Front Plant. Sci. - 2019. - Access mode : https://doi.org/10.3389/fpls.2018.02006.

4. Linster C. L. L-Ascorbate biosynthesis in higher plants: The role of VTC2 / C. L. Linster, S. G. Clarke // Trends in Plant Science. - 2008. - 13, No. 11. P. 567-573.

5. Pallanca J. E. The control of ascorbic acid synthesis and turnover in pea seedlings / J. E. Pallanca, N. Smirnoff // J. Exp. Bot. - 2000. - 51, No. 345. P. 669-674.

6. Conklin P. L. Recent advances in the role and biosynthesis of ascorbic acid in plants / P. L. Conklin // Plant, Cell and Environment. - 2001. - 24, No. 4. -
P. 384-394. - Access mode : https://doi.org/10.1046/ j.1365-3040.2001.00686.x.

7. Noctor $\mathrm{G}$. The roles of reactive oxygen metabolism in drought: not so cut and dried / G. Noctor, A. Mhamdi, C. H. Foyer // Plant Physiol. - 2014. - 164. - P. 16361648.

8. Воробець Н. М. Функціонування аскорбатпероксидази та вміст аскорбінової та дегідроаскорбінової кислот у проростаючого насіння соняшника та квасолі під дією різних доз свинцю / Н.М.Воробець // Наук. вісн. Ужгород. нац. ун-ту. Серія "Біологія". 2003. - № 13. - C. 53-56.

9. Gallie D.R. The role of I-ascorbic acid recycling in responding to environmental stress and in romoting plant growth/D.R. Gallie // J. Exp. Bot. -2013. -64. -P. 433-443.

10. Manipulation of ascorbiate biosynthetic, recycling and regulatory pathways for improved abiotic stress tolerance in plants / R. C. Broad, J. P. Bonneau, R. P. Hellens, A. A. T. Johnson // Int. J. Mol. Sci. - 2020 - 21, No. 5. - P. 790. DOI: 10.3390/ijms21051790.

11. Light regulation of ascorbate biosynthesis is dependent on the photosynthetic electron transport chain 
but independent of sugars in Arabidopsis / Y. Yabuta, T. Mieda, M. Rapolu [et al.] // J. Exp. Bot. - 2007. - 58, No. 10. - P. 2661-2671.

12. A single portion of blueberry (Vaccinium corymbosum L.) improves protection against DNA damage but not vascular function in healthy male volunteers / C. Del Bo, P. Riso, J. Campolo [et al.] // Nutr. Res. - 2013. 33. - P. 220-227.

13. Smirnoff N. Ascorbic acid metabolism and functions: a comparison of plants and mammals / N. Smirnoff // Free Radic. Biol. Med. - 2018. - 122. P. 116-129.

14. Saito K. Conversion of D-glucosone to oxalic acid and L-(+)-tartaric acid in detached leaves of Pelargonium / K. Saito, F. A. Loewus // Phytochemistry. - 1992. - 31. P. 3341-3344. - Access mode : https://doi. org/10.1016/0031-9422(92)83681-N.

15. Organic acid metabolism in plants: From adaptive physiology to transgenic varieties for cultivation in extreme soils / J. Lo' pez-Bucio, M. F. Nieto-Jacobo, V. Ramirez-Rodriguez, L. Herrera-Estrella // Plant Science. -2001. -160, No. 1. - P. 1-13.

16. Increasing ascorbate levels in crops to enhance human nutrition and plant abiotic stress tolerance / R. C. Macknight, W. A. Laing, S. M. Bulley [et al.] // Curr. Opin. Biotechnol. - 2017. - 44. - P. 153-160.

17. Du J. Ascorbic acid: chemistry, biology and the treatment of cancer / J. Du, J. J. Cullen, G. R. Buettner // BBA. - 2012. - 1826. - P. 443-457.

18. Myllyharju, J. Prolyl 4-hydroxylases, key enzymes in the synthesis of collagen and regulation of the response to hypoxia, and their roles as treatment targets / J. Myllyharju // Ann. Med. - 2008. - 40, No. 6. - P. 402-417.

19. Van Vlies N. Measurement of carnitine biosynthesis enzyme activities by tandem mass spectrometry: differences between the mouse and the rat / N. Van Vlies, R. J. Wanders, F. M. Vaz // Anal. Biochem. -2006. 354, No. 1. - P. 132-139.

20. Molecular mechanism and nealth role of functional ingredients in blueberry for xhronic disease in human beings / L. Ma, Z. Sun, Y. Zeng [et al.] // Int. J. Mol. Sci. - 2018. - 19, No. 9. - E2785. DOI: 10.3390/ ijms19092785.

21. Linster C. L. Vitamin C: biosynthesis, recycling and degradation in mammals / C. L. Linster, E. Van Schaftingen // FEBS J. - 2007 - 274. - P. 1-22.

\section{REFERENCES}

1. Davey, M.W., Van Montagu, M., Inzé, D., Sanmartin, M., Kanellis, A., Smirnoff, N., et al. (2000) Plant L-ascorbic acid: chemistry, function, metabolism, bio availability and effects of processing. J. Sci. Food Agric., 80, 825-860.

2. Smirnoff, N., \& Wheeler, G.L. (2000) Ascorbic acid in plants: biosynthesis and function. Crit. Rev. Biochem. Mol. Biol., 35(4), 291-314.

3. Fenech, M., Amaya, I., Valpuesta, V., \& Botella, M.A. (2019). Vitamin C content in fruits: biosynthesis and regulation. Front Plant Sci. Retrieved from: https://doi. org/10.3389/fpls.2018.02006.
22. Liato V. Influence of electro-activated solutions of weak organic acid salts on microbial quality and overall appearance of blueberries during storage / V. Liato, R. Hammami, M. Aïder // Food Microbiol. - 2017. - 64. P. 56-64.

23. Diaconeasa Z. Time-dependent degradation of polyphenols from thermally-processed berries and their in vitro antiproliferative effects against melanoma / Z. Diaconeasa // Molecules. - 2018. - 23, No.10. - P. 2534. DOI: $10.3390 /$ molecules23102534.

24. Yavorska N. The effect of variation of harvest season on water soluble BAS in shoots of Vaccinium corymbosum L. / N. Yavorska, N. Vorobets // Book Abstracts. 4thInternational Conference on Natural Products Utilization: from Plants to Pharmacy Shelf. Albena resort, Bulgaria, 29 May-01 June; 2019. - 348 p.

25. Vorobets N. Phytosynthetic pigments in shoots of Vaccinium corymbosum L. (cv. Elliott) / N. Vorobets, N. Yavorska // Agrobiodiversity for Improving Nutrition, Health and Life Quality; Ed.: J. Brindza, S. Klymenko. Slovak Univ. of Agriculture in Nitra. - 2019. - P. 93-100. ISBN 978-80-552-2108-3. - Access mode : http: //doi. org/10.15414/agrobiodiversity.2019.2585-8246.093-100.

26. Hewitt E. J. Spectrophotometric measurements on ascorbic acid and their use for the estimation of ascorbic acid and dehydroascorbic acid in plant tissue I E. J. Hewitt, G. J. Dickes // The Biochem. J. - 1961 - 78, No. 2. - P. 384-391.

27. Державна Фармакопея України / Державне підприємство "Український науковий фрармакопейний центр якості лікарських засобів". - 2-ге вид. - Харків : Державне підприємство "Український науковий фрармакопейний центр якості лікарських засобів", 2015. 1. $-1128 \mathrm{c}$.

28. Guarnieri S. Orange juice vs vitamin C: Effect on hydrogen peroxide-induced DNA damage in mononuclear blood cells / S. Guarnieri, P. Riso, M. Porrini // Br. J. Nutr. - 2007. - 97 (4). - P. 639-643.

29. Beck K. Gold kiwifruit consumed with an ironfortified breakfast cereal meal improves iron status in women with low iron stores: a 16-week randomised controlled trial / K. Beck, C. A. Conlon, R. Kruger [et al.] // Br. J. Nutr. - 2011. - 105, No. 1. - P. 101-109.

30. Tugnoli B. From acidifiers to intestinal health enhancers: How organic acids can improve growth efficiency of pigs / B. Tugnoli, G. Giovagnoni, A. Piva, E. Grilli // Animals. - 2020-10, No 1. - P. 134. - Access mode : https://doi.org/10.3390/ani10010134

4. Linster, C.L., \& Clarke, S.G. (2008) L-Ascorbate biosynthesis in higher plants: The role of VTC2. Trends in Plant Science, 13 (11), 567-573.

5. Pallanca, J.E., \& Smirnoff, N. (2000). The control of ascorbic acid synthesis and turnover in pea seedlings. J. Exp. Bot., 51(345), 669-674.

6. Conklin, P.L. (2001) Recent advances in the role and biosynthesis of ascorbic acid in plants. Plant, Cell and Environment, 24 (4), 384-394.

7. Noctor, G., Mhamdi, A., \& Foyer, C.H. (2014). The roles of reactive oxygen metabolism in drought: not so cut and dried. Plant Physiol., 164, 1636-1648. 
8. Vorobets, N.M. (2003). Funktsionuvannia askorbatperoksydazy ta vmist askorbinovoli ta dehidroaskorbinovoi kyslot u prorostaiuchomu nasinni soniashnyku ta kvasoli pid diieiu riznykh doz svyntsiu [Functioning of ascorbate peroxidase and the content of ascorbic and dehydroascorbic acids in germinating sunflower and bean seeds under the action of different doses of lead]. Naukovyi visnyk Uzhhorodskoho natsionalnoho un-tu. Ser. biol. - Scientific Bul. Uzhhorod National Univ. Ser. Biol.,13, 53-56 [in Ukrainian].

9. Gallie, D.R. (2013). The role of I-ascorbic acid recycling in responding to environmental stress and in romoting plant growth. J. Exp. Bot., 64, 433-443.

10. Broad, R.C., Bonneau, J.P., Hellens, R.P., \& Johnson, A.A.T. (2020) Manipulation of ascorbiate biosynthetic, recycling and regulatory pathways for improved abiotic stress tolerance in plants. Int. J. Mol. Sci., 21 (5), 790.

11. Yabuta, Y., Mieda, T., Rapolu, M., Nakamura, A., Motoki, T., \& Maruta, T., et al. (2007). Light regulation of ascorbate biosynthesis is dependent on the photosynthetic electron transport chain but independent of sugars in Arabidopsis. J. Exp. Bot., 58(10), 2661-2671.

12. Del Bo, C., Riso, P., Campolo, J., Moller, P., Loft, S., Klimis-Zacas, D., et al. (2013). A single portion of blueberry (Vaccinium corymbosum L.) improves protection against DNA damage but not vascular function in healthy male volunteers. Nutr. Res., 33, 220-227.

13. Smirnoff, N. (2018). Ascorbic acid metabolism and functions: a comparison of plants and mammals. Free Radic. Biol. Med., 122, 116-129.

14. Saito, K., \& Loewus, F.A. (1992). Conversion of D-glucosone to oxalic acid and L-(+)-tartaric acid in detached leaves of Pelargonium. Phytochemistry, 31, 3341-3344.

15. Lo' pez-Bucio, J., Nieto-Jacobo, M.F., RamirezRodriguez, V., \& Herrera-Estrella, L. (2001). Organic acid metabolism in plants: From adaptive physiology to transgenic varieties for cultivation in extreme soils. Plant Science, 160 (1), 1-13.

16. Macknight, R.C., Laing, W.A., Bulley, S.M., Broad, R.C., Johnson, A.A., \& Hellens, R.P. (2017). Increasing ascorbate levels in crops to enhance human nutrition and plant abiotic stress tolerance. Curr. Opin. Biotechnol., 44, 153-160.

17. Du, J., Cullen, J.J., \& Buettner, G.R. (2012). Ascorbic acid: chemistry, biology and the treatment of cancer. BBA, 1826, 443-457.

18. Myllyharju, J. (2008). Prolyl 4-hydroxylases, key enzymes in the synthesis of collagen and regulation of the response to hypoxia, and their roles as treatment targets. Ann. Med., 40(6), 402-417.

19. Van Vlies, N., Wanders, R.J., \& Vaz, F.M. (2006). Measurement of carnitine biosynthesis enzyme activities by tandem mass spectrometry: differences between the mouse and the rat. Anal. Biochem., 354 (1), 132-139.
20. Ma, L., Sun, Z., Zeng, Y., Luo, M., \& Yang, J. (2018). Molecular mechanism and nealth role of functional ingredients in blueberry for xhronic disease in human beings. Int. J. Mol. Sci., 19(9), E2785.

21. Linster, C.L., \& Van Schaftingen, E. (2007). Vitamin C: biosynthesis, recycling and degradation in mammals. FEBS J., 274, 1-22.

22. Liato, V., Hammami, R., \& Aïder, M. (2017). Influence of electro-activated solutions of weak organic acid salts on microbial quality and overall appearance of blueberries during storage. Food Microbiol., 64, 56-64.

23. Diaconeasa, Z. (2018). Time-dependent degradation of polyphenols from thermally-processed berries and their in vitro antiproliferative effects against melanoma. Molecules, 23 (10), 2534.

24. Yavorska, N., \& Vorobets, N. (2019). The effect of variation of harvest season on water soluble BAS in shoots of Vaccinium corymbosum L. Book Abstracts. 4th International Conference on Natural Products Utilization: from Plants to Pharmacy Shelf. Albena resort, Bulgaria.

25. Vorobets, N., \& Yavorska, N. (2019). Phytosynthetic pigments in shoots of Vaccinium corymbosum $L$. (cv. Elliott). Agrobiodiversity for Improving Nutrition, Health and Life Quality; Ed.: J.Brindza, S.Klymenko. Slovak Univ. of Agriculture in Nitra. ISBN 978-80-552-2108-3. Retrieved from: http: //doi.org/10.15414/agrobiodiversi ty.2019.2585-8246.093-100.

26. Hewitt, E.J., \& Dickes, G.J. (1961). Spectrophotometric measurements on ascorbic acid and their use for the estimation of ascorbic acid and dehydroascorbic acid in plant tissue. The Biochem. J., 78 (2), 384-391. DOI: 10.1042/bj0780384. (2015).

27. Derzhavna Farmakopeia Ukrainy: $v 3$ t. Derzhavne pidpryiemstvo "Ukrainskyi naukovyi farmakopeinyi tsentr yakosti likarskykh zasobiv" [State Pharmacopeia of Ukraine: in 3 vol. / State Enterprise "Ukrainian Scientific Pharmacopoeial Centre of Medicinal drugs Quality]. Kharkiv: Derzhavne pidpryiemstvo "Ukrainskyi naukovyi farmakopeinyi tsentr yakosti likarskykh zasobiv" [in Ukrainian].

28. Guarnieri, S., Riso, P., \& Porrini, M. (2007). Orange juice vs vitamin C: Effect on hydrogen peroxideinduced DNA damage in mononuclear blood cells. Br. J. Nutr., 97 (4), 639-643.

29. Beck, K., Conlon, C.A., Kruger, R., Coad, J., \& Stonehouse, W. (2011). Gold kiwifruit consumed with an iron-fortified breakfast cereal meal improves iron status in women with low iron stores: a 16-week randomised controlled trial. Br. J. Nutr., 105 (1),101-109.

30. Tugnoli, B., Giovagnoni, G., Piva, A., \& Grilli, E. (2020). From acidifiers to intestinal health enhancers: How organic acids can improve growth efficiency of pigs. Animals., 10 (1), 134. Retrieved from: https://doi. org/10.3390/ani10010134 


\section{СЕЗОННІ ЗМІНИ ВМІСТУ АСКОРБІНОВОЇ ТА ОРГАНІЧНИХ КИСЛОТ У ПАГОНАХ ЛОХИНИ ВИСОКОРОСЛОЇ РІЗНИХ СОРТІВ ПРОТЯГОМ ПЕРІОДУ ВЕГЕТАЦІї}

\section{Резюме}

Вступ. Аскорбінова кислота (АК) та органічні кислоти (ОК) синтезуються в усіх рослинах і є важливою частиною їх метаболізму, а також невід'ємною частиною метаболізму людського організму. Дослідженню механізмів діїї екстрактів передує детальне вивчення складу, зокрема АК та ОК, вміст яких може змінюватися на різних фрізіологічних фразах розвитку.

Мета дослідження - визначити вміст аскорбінової та органічних кислот у пагонах лохини високорослої трьох сортів на різних стадіях їх фрізіологічного розвитку.

Meтоди дослідження. Матеріалом для дослідження були пагони лохини високорослої (Vaccinium Corymbosum L.) сортів Блюджей, Блюкроп та Еліот. Вміст аскорбінової кислоти визначали спектрооротометричним методом, описаним Hewitt, Dickes (1961), вміст органічних кислот в екстрактах - за Державною Фармакопеєю України (2015).

Результати й обговорення. Одержані результати продемонстрували високий вміст АК та ОК у пагонах лохини високорослої досліджуваних сортів. Під час аналізу встановили, що він майже збігався в цих сортах. Вміст АК перебував на рівні 42,61-83,62 мг.100 $2^{-1}$ сухої маси (СМ) (найнижчий показник -

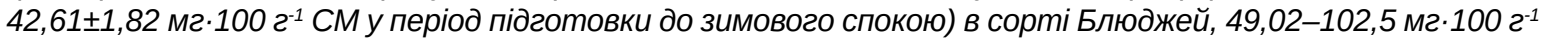
СМ - у сорті Блюкроп, 70,87-98,04 ма.100 2-1 CM - у сорті Еліот. Вміст ОК змінювався в межах 2,19-5,26 \% у сорті Блюджей, 3,12-7,83 \% - у сорті Блюкроп та 3,80-9,16 \% - у сорті Еліот.

Висновки. Сорти лохини високорослої з різними термінами дозрівання плодів відрізняються за вмістом аскорбінової та органічних кислот у пагонах протягом періоду вегетації. Результати нашого дослідження свідчать про те, що пагони V. corymbosum сортів Блюджей, Блюкроп та Еліот мають достатньо високий вміст аскорбінової й органічних кислот і можуть бути використані для подальшого вивчення механізмів дії їх екстрактів як лікувальних засобів для профрілактики різних захворювань, пов'язаних 3 вільними радикалами та порушеннями обміну речовин у людини і тварин.

КЛЮЧОВІ СЛОВА: Vaccinium corymbosum L.; сорти Блюджей, Блюкроп, Еліот; аскорбінова кислота; органічні кислоти.

Н. И. Яворская, Н. Н. Воробец ЛЬВОВСКИЙ НАЦИОНАЛЬНЫЙ МЕДИЦИНСКИЙ УНИВЕРСИТЕТ ИМЕНИ ДАНИЛА ГАЛИЦКОГО

\section{СЕЗОННЫЕ ИЗМЕНЕНИЯ СОДЕРЖАНИЯ АСКОРБИНОВОЙ И ОРГАНИЧЕСКИХ КИСЛОТ В ПОБЕГАХ ГОЛУБИКИ ВЫСОКОРОСЛОЙ РАЗЛИЧНЫХ СОРТОВ В ТЕЧЕНИЕ ПЕРИОДА ВЕГЕТАЦИИ}

\section{Резюме}

Вступление. Аскорбиновая кислота (АК) и органические кислоты (ОК) синтезируются во всех растениях и являются важной частью их метаболизма, а также неотъемлемой частью метаболизма человеческого организма. Исследованию механизмов действия их экстрактов предшествует детальное изучение состава, в частности АК и ОК, содержание которых может меняться в различных фризиологических фразах развития.

Цель исследования - определить содержание аскорбиновой и органических кислот в побегах голубики высокорослой трех сортов на разных стадиях их фризиологического развития.

Методы исследования. Материалом для исследования были побеги голубики высокорослой (Vaccinium Corymbosum L.) сортов Блюджей, Блюкроп и Эллиотm. Содержание аскорбиновой кислоты определяли спектрофротометрическим методом, описанным Hewitt, Dickes (1961), содержание органических кислот в экстрактах - по Государственной Фармакопее Украины (2015).

Результаты и обсуждение. Полученные результаты продемонстрировали высокое содержание АK и ОК в побегах голубики высокорослой исследуемых сортов. Во время анализа установили, что он почти 
совпадал в этих сортах. Содержание АК было на уровне 42,61-83,62 м2·100 2-1 сухой массы (СМ) (самый

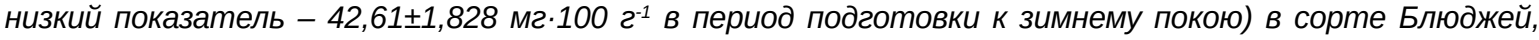
49,02-102,5 мг·100 2-1 CM - в сорте Блюкроп, 70,87-98,04 мг·100 2-1 CM - в сорте Эллиотт. Содержание ОК менялось в пределах 2,19-5,26 \% в сорте Блюджей, 3,12-7,83 \% - в сорте Блюкроп и 3,80-9,16 \% - в сорте Эллиотm.

Выводы. Сорта голубики высокорослой с разными сроками созревания плодов отличаются по содержанию аскорбиновой и органических кислот в побегах в течение периода вегетации. Результаты нашего исследования свидетельствуют о том, что побеги V. corymbosum сортов Блюджей, Блюкроп и Эллиотm имеют достаточно высокое содержание аскорбиновой и органических кислот и могут быть использованы для дальнейшего изучения механизмов действия их экстрактов как лечебных средств для профилактики различных заболеваний, связанных со свободными радикалами и нарушениями обмена веществ у человека и животных.

КЛЮЧЕВЫЕ СЛОВА: Vaccinium corymbosum L.; сорта Блюджей, Блюкроп, Эллиотт; аскорбиновая кислота; органические кислоты.

Received 12.05.20

Address for correspondence: N. M. Vorobets, Danylo Halytsky Lviv National Medical University, Pekarska Str. 69, Lviv, 79010, Ukraine, e-mail: vorobets_natalia@meduniv.Iviv.ua. 